\title{
Partial Results on the Degeneration of Potato in the Microzones for Seed Potato Production at Tg. Secuiesc and Apa Roșie
}

\author{
Robert MOTICA* \\ Potato Research and Development Station Tg. Secuiesc \\ * corresponding author: poszto@yahoo.com \\ Bulletin USAMV series Agriculture 71(2)/2014 \\ Print ISSN 1843-5246; Electronic ISSN 1843-5386 \\ DOI 10.15835/buasvmcn-agr: 10841
}

\begin{abstract}
After the transition of agriculture to market economy the competition has become fierce, so it is very important to increase farm productivity. For a higher production with lower costs you need healthy and productive planting material. Potato producers in Romania and Covasna County have to face for a long time with seed potato degeneration. The team from the Potato Research and Development Station Tg. Secuiesc aims to carry out simultaneous experiments for this purpose. At the Potato Research and Development Station Tg. Secuiesc are followed both the virotic and physiological degeneration of the potato. Since 2011 many experiments have been established in the research fields in Tg. Secuiesc and at the amelioration station Apa Roşie. For each experiments was used the same variety and the same biological category. The results obtained so far show that the indigenous varieties obtained under the climatic conditions in Romania are more resistant to the virotic degeneration than the imported varieties and in many cases yields obtained are similar.
\end{abstract}

Keywords: disease, potato, variety, virotic degeneration

\section{INTRODUCTION}

The potato virotic degeneration is now widely accepted throughout the world, and the knowledge of this phenomenon constitutes the basis of the seed potato production and multiplication systems. The plant viruses are pathogens that multiply inside the plant cells and migrate with similar substances in the plant and in the tuber as well. The viruses are transmitted from plant to plant by aphids, cicada, fungi, and nematodes or by contact between plants. Virotic diseases are not visible on the tubers without the use of special equipment and in order to keep the seed potato virotic disease free, fields should be cultivated by applying special technologies for seed potato. On the Romanian market are currently over 400 potato varieties, of which over $80 \%$ are varieties imported from Europe. Most of these imported potato varieties are not adapted to the climatic conditions in our country, which leads to a higher virotic degeneration compared to the varieties produced by local researchers. At SCDC Tg. Secuiesc the Plant Protection Section keeps under observation the imported varieties regarding the virotic degeneration since 2011, using the Gared variety as experimental subject, which was created at SCDC Tg. Secuiesc.

\section{MATERIALS AND METHODS}

In the experimentation years of 2011-2012 were planted 12 varieties of the biological category Base Class Elite, and there were determined in each year the number of plants infected with viruses at the time when the plants were 30-40 $\mathrm{cm}$ tall before the flowering phenophase using the serological method. The virotic infections were monitored and followed: potato leafroll virus, virus $S$, virus $Y$ and virus $M$. the experiments were carried out in two places, in the experimental field in Tg. Secuiesc and in the micro-region Apa Roşie at an altitude of over $1000 \mathrm{~m}$. The varieties in this study were the indigenous varieties: Gared, 
Nemere, Tentant,Cristian, Astral, Magic; foreign varieties: Kondor, Arnova, Agata, Riviera, Impala, Bellarosa.

\section{RESULTS AND DISCUSSION}

In 2012 was registered a smaller amount of rain of $264.1 \mathrm{~mm}$ during the growing season, the difference compared to MMA was $115.9 \mathrm{~mm}$, the year 2012 was unfavorable for potato crop. In April and May there were large amounts of precipitation compared to MMA, with $+38,2 \mathrm{~mm}$ and $33,7 \mathrm{~mm}$. In June and July the amount of rainfall recorded in $\mathrm{Tg}$. Secuiesc was very small, so in June compared to MMA the deficit was $71,9 \mathrm{~mm}$ and in July 67,1 $\mathrm{mm}$. The climatic conditions were unfavorable for mildew and blight during the growing season.

The frequency of days with rainfall larger than $5 \mathrm{~mm}$ is very important because it hinders the aphid flight, the frequency of days with rain is very important especially in May, June and July when the aphid population development is very intense.

Analyzing the 12 varieties studied in the experiment concerning the percentage of the infected plants in 2011can be observed that the most affected variety was the Impala variety showing the lowest total production of tubers. (Tab. 2)

The most virus resistant variety was the Gared variety, showing the lowest percentage of viruses.

Comparing indigenous varieties to imported varieties we can observe that the Romanian varieties are much more resistant than the imported ones.

The Agata and Impala varieties were heavily infected with the potato leafroll virus, 2,56 of the plants were seriously infected. The Agata, Impala and Riviera varieties were the only varieties infected with the virus $Y$, the rest of the varieties remained free of it. Each variety in study was infected with the potato virus $\mathrm{S}$.

In 2012, due to the unfavorable weather conditions for the activity of virus vector aphids at SCDC Tg. Secuiesc there were identified fewer virus vector insects, however the percentage of virus-infected plants has increased significantly compared to 2011.

This year the yields obtained were with 50 \% lower than in 2011 due to the unprecedented weather conditions, but this depreciation in yield is not relevant in terms of virotic degeneration.

Tab. 1. Rainfall situation in Târgu Secuiesc during 2002-2012

\begin{tabular}{|c|c|c|c|c|c|c|c|c|c|c|c|c|}
\hline $\begin{array}{l}\text { Months of } \\
\text { the year }\end{array}$ & $\begin{array}{l}\text { Year } \\
2002 \\
\end{array}$ & $\begin{array}{l}\text { Year } \\
2003 \\
\end{array}$ & $\begin{array}{l}\text { Year } \\
2004 \\
\end{array}$ & $\begin{array}{l}\text { Year } \\
2005 \\
\end{array}$ & $\begin{array}{l}\text { Year } \\
2006 \\
\end{array}$ & $\begin{array}{l}\text { Year } \\
2007 \\
\end{array}$ & $\begin{array}{l}\text { Year } \\
2008 \\
\end{array}$ & $\begin{array}{l}\text { Year } \\
2009 \\
\end{array}$ & $\begin{array}{l}\text { Year } \\
2010 \\
\end{array}$ & $\begin{array}{l}\text { Year } \\
2011 \\
\end{array}$ & $\begin{array}{l}\text { Year } \\
2012 \\
\end{array}$ & MMA \\
\hline January & 28,2 & 20,7 & 23,0 & 7,4 & 18,2 & 26,1 & 11,3 & 11,7 & 40,8 & 16,5 & 29.9 & 21,3 \\
\hline February & 8,6 & 40,2 & 34,8 & 20,4 & 7,3 & 26,3 & 6,3 & 9,3 & 15,2 & 14,3 & 24.8 & 20,2 \\
\hline March & 24,7 & 17,3 & 25,2 & 30,0 & 20,4 & 28,5 & 22,2 & 14,4 & 28,3 & 7,4 & 23.9 & 21,5 \\
\hline April & 30,2 & 50,6 & 48,0 & 40,0 & 47,2 & 21,6 & 59,9 & 9,4 & 35,8 & 50,2 & 76.7 & 38,5 \\
\hline May & 61,7 & 37,2 & 46,6 & 24,0 & - & 27,4 & 68,8 & 87,2 & 112,2 & 54,3 & 104.5 & 70,8 \\
\hline June & 75,4 & 35,4 & 20,8 & 119,0 & 105,4 & 45,7 & 61,6 & 114,7 & 158,0 & 132,6 & 12.1 & 84,0 \\
\hline July & 140,6 & 98,4 & 117,8 & 110,4 & 42,8 & 49,6 & 122,0 & 78,3 & 129,2 & 51,5 & 11.1 & 78,7 \\
\hline August & 65,0 & 49,2 & 106,6 & 139,2 & 160,2 & 99,8 & 38,0 & 30,9 & 118,5 & 49,5 & 22.2 & 62,7 \\
\hline September & 44,5 & 45,2 & 57,4 & 70,2 & 55,4 & 40,1 & 26,5 & 35,5 & 38,1 & 6,1 & 37.5 & 45,3 \\
\hline Octomber & 29,6 & 76,6 & 16,6 & 16,6 & 23,3 & 31,4 & 85,9 & 49,3 & 30,0 & 34,2 & 16.9 & 31,3 \\
\hline November & 36,5 & 13,2 & 32,0 & 32,0 & 14,9 & 23,3 & 18,7 & 13,6 & 27,6 & - & 13.1 & 27,7 \\
\hline December & 12,6 & 9,6 & 6,0 & 6,0 & 8,1 & 41,7 & 33,6 & 32,5 & 44,8 & 30,5 & 37.3 & 23,7 \\
\hline Total & 557,6 & 493,6 & 537,4 & 615,2 & 503,2 & 461,5 & 554,8 & 486,8 & 778,5 & 447,1 & 410 & 525,7 \\
\hline $\begin{array}{l}\text { Total rainfall } \\
\text { during the } \\
\text { growing } \\
\text { season }\end{array}$ & 417,4 & 316 & 397,2 & 502,4 & 411 & 284,2 & 376,8 & 356 & 591,8 & 344,2 & 264.1 & 380 \\
\hline
\end{tabular}




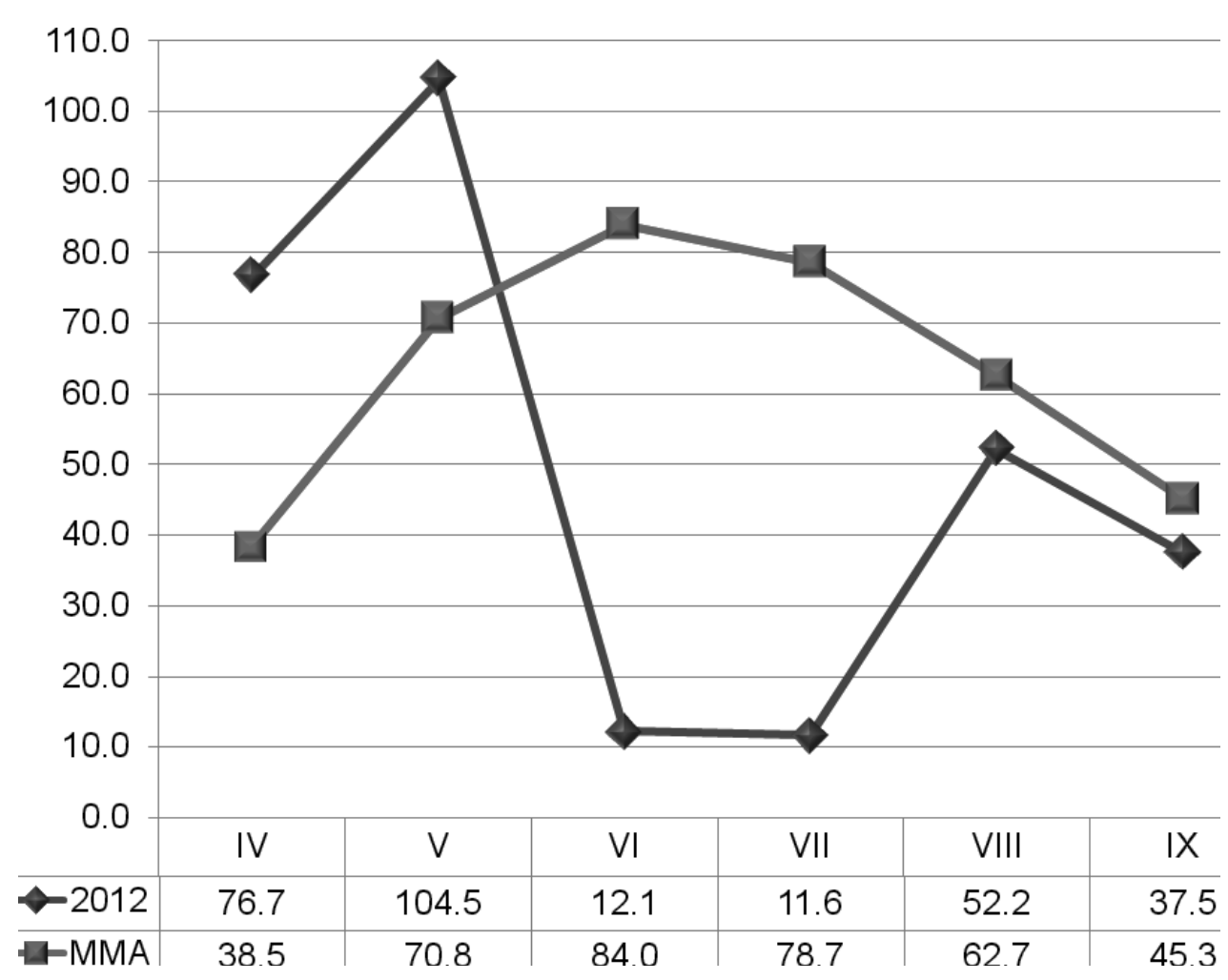

Fig. 1. Changes in rainfall during the growing season (April-September) in 2012 compared to normal amounts recorded at the Meteorological Station in Tg. Secuiesc

Tab 2. Percentage of virus-infected plants in the experimental field in Târgu Secuiesc during the experimentation years 2011-2012.

\begin{tabular}{|c|c|c|c|c|c|c|c|c|c|c|c|c|}
\hline \multirow{3}{*}{ Variety } & \multicolumn{10}{|c|}{$\%$ of virus-infected plants } & \multirow{2}{*}{\multicolumn{2}{|c|}{$\begin{array}{c}\text { Average } \\
\text { production } \\
\text { t/ha }\end{array}$}} \\
\hline & \multicolumn{2}{|c|}{$\begin{array}{c}\text { Potato } \\
\text { leafroll virus }\end{array}$} & \multicolumn{2}{|c|}{ S } & \multicolumn{2}{|c|}{$\mathrm{Y}$} & \multicolumn{2}{|c|}{ M } & \multicolumn{2}{|c|}{ Erwinia } & & \\
\hline & 2011 & 2012 & 2011 & 2012 & 2011 & 2012 & 2011 & 2012 & 2011 & 2012 & 2011 & 2012 \\
\hline Gared & - & - & 1.25 & 2.66 & - & - & - & - & - & - & 41.10 & 7.11 \\
\hline Nemere & 1.25 & 2.50 & 2.08 & 4.58 & - & - & - & - & - & - & 36.46 & 5.15 \\
\hline Tentant & 1.66 & 2.83 & 5.41 & 6.32 & - & 1.25 & - & - & - & - & 34.88 & 4.78 \\
\hline Christian & - & 1.25 & 2.32 & 2.75 & - & - & - & - & - & - & 37.81 & 6.87 \\
\hline Astral & - & 1.25 & 4.00 & 5.33 & - & 0.83 & - & - & - & - & 36.12 & 6.26 \\
\hline Magic & 1.25 & 1.25 & 2.32 & 6.08 & - & - & - & - & - & - & 36.75 & 5.71 \\
\hline Kondor & - & - & 2.07 & 4.16 & - & - & - & - & - & - & 43.77 & 5.66 \\
\hline Arnova & 1.66 & 2.75 & 6.07 & 7.08 & - & 0.83 & - & - & - & - & 51.76 & 7.61 \\
\hline Agata & 2.56 & 2.83 & 6.32 & 8.58 & 1.25 & 2.08 & - & - & - & - & 29.00 & 4.22 \\
\hline Riviera & 1.56 & 2.08 & 6.16 & 8.73 & 1.25 & 1.66 & - & - & - & - & 36.95 & 4.90 \\
\hline Impala & 2.56 & 2.75 & 6.32 & 8.78 & 1.25 & 1.66 & - & - & - & - & 21.05 & 5.95 \\
\hline Bella Rosa & - & 1.25 & 2.08 & 4.00 & - & - & - & - & - & - & 44.08 & 6.43 \\
\hline
\end{tabular}


Tab 3. Percentage of virus-infected plants in the experimental field in Apa Roşie during the experimentation years 2011-2012.

\begin{tabular}{|c|c|c|c|c|c|c|c|c|c|c|c|c|}
\hline \multirow{3}{*}{ Variety } & \multicolumn{10}{|c|}{$\%$ of virus-infected plants } & \multirow{2}{*}{\multicolumn{2}{|c|}{$\begin{array}{c}\text { Average } \\
\text { production } \mathrm{t} / \\
\text { ha }\end{array}$}} \\
\hline & \multicolumn{2}{|c|}{$\begin{array}{l}\text { Potato } \\
\text { leafroll virus }\end{array}$} & \multicolumn{2}{|c|}{$\mathrm{S}$} & \multicolumn{2}{|c|}{ Y } & \multicolumn{2}{|c|}{ M } & \multicolumn{2}{|c|}{ Erwinia } & & \\
\hline & 2011 & 2012 & 2011 & 2012 & 2011 & 2012 & 2011 & 2012 & 2011 & 2012 & 2011 & 2012 \\
\hline Gared & - & 1.25 & 1.25 & 2.08 & - & - & - & - & - & - & 15.27 & 4.21 \\
\hline Nemere & - & - & 1.66 & 1.66 & - & - & - & - & - & - & 17.00 & 4.56 \\
\hline Tentant & - & 1.66 & 2.08 & 3.75 & - & - & - & - & - & - & 13.68 & 4.23 \\
\hline Christian & 0.83 & 1.25 & 1.66 & 2.08 & - & 1.25 & - & - & - & - & 13.77 & 6.14 \\
\hline Astral & - & 1.25 & 1.87 & 2.08 & - & - & - & - & - & - & 15.02 & 3.78 \\
\hline Magic & 0.83 & 1.66 & 1.66 & 2.08 & - & 1.25 & - & - & - & - & 14.31 & 3.34 \\
\hline Kondor & - & 1.25 & 1.25 & 2.50 & - & - & - & - & - & - & 11.45 & 5.01 \\
\hline Arnova & 1.25 & 1.66 & 2.91 & 3.25 & - & 1.25 & - & - & - & - & 16.35 & 6.79 \\
\hline Agata & 2.08 & 2.50 & 3.75 & 4.66 & 1.25 & 1.66 & - & - & - & - & 12.64 & 3.60 \\
\hline Riviera & 2.50 & 1.66 & 5.25 & 5.00 & 1.25 & 1.66 & - & - & - & - & 10.57 & 4.04 \\
\hline Impala & 1.66 & 1.66 & 4 & 6.25 & 1.25 & 1.25 & - & - & - & - & 10.39 & 5.05 \\
\hline Bella Rosa & - & 1.66 & 1.66 & 2.50 & - & - & - & - & - & - & 12.66 & 5.49 \\
\hline
\end{tabular}

Comparing foreign varieties to indigenous ones it can be observed that the Romanian varieties are more resistant to virotic degeneration. Compared to the previous year 2011 the percentage of virusinfected plants has increased seriously.

The most infected varieties were the imported varieties Agata, Riviera and Impala, there were no infections with the bacteria Erwinia carotovora.

The Amelioration Station of the Potato Research and Development Station Târgu Secuiesc is situated at an altitude of $1000 \mathrm{~m}$, at this altitude the climatic conditions are not favorable for virus vector aphids. The Potato Research and Development Station Târgu Secuiesc cannot study the population of aphids in the experimnetal field at Apa Roșie due to inappropriate living conditions there, thus it is only presupposed the absence or the low number of virus vector insects in the experimental fields at Apa Roșie.

The most infected varieties during the experimentation years 2011-2012 were the imported varieties Agata, Riviera and Impala. These varieties were the only ones that showed potato virus $Y$ attack.

The most resistant varieties in this regard were Gared and Bella Rosa varieties (Tabel 3). Analyzing the percentage of virus-infected plants in the two microzones for seed potato cultivation is found that in the microzone Apa Roşie the percentage of virus-infected plants is much lower than in Târgu Secuiesc due to the low number of virus vector aphids.

\section{CONCLUSIONS AND \\ RECOMMENDATIONS}

In 2012 was recorded the lowest rainfall, 194,3 $\mathrm{mm}$ during the growing season, the difference compared to MMA being 77,7 mm, the year 2012 was considered an unfavorable year for potato crop. In April and May there were large amounts of precipitation compared to MMA, with $+38,2 \mathrm{~mm}$ and $33,7 \mathrm{~mm}$.

The seed potato production in both microzones was higher in the case of indigenous varieties than in the case of imported varities, so imported varieties have a larger production capacity of potato for consumtpion.

During the experimentation years the indigenous varieties showed better resistance to virotic degeneration in both microzones of potato production Târgu Secuiesc and Apa Roşie.

The most sensitive variety to virotic degeneration during the experimentation year was the 
imported variety Impala in both microzones for seed potato production.

The most resistant variety to virotic degeneration was the indigenous variety Gared in both microzones for seed potato production.

During the experimental years 2011-2012 there had not been observed any Erwinia carotovora attacks in the experimetal fields in Târgu Secuiesc and Apa Roşie.

\section{REFERENCES}

1. Cojocaru N. (1995). Principalele virusuri ale cartofului, pagube şi simptome. Cartoful în România, vol. 5, nr. 2-3, apr.-sept. Pag. 29-31.

2. Donescu Daniela (1995). Principalele specii de afide în cultura de cartof (descriere, biologie, plante gazde) Analele I.C.P.C. Braşov, vol. XXII.

3. Draica C. (2004). Modernizarea tehnologiei de producere a cartofului pentru sămânţă. Editura Phoenix, pag. 1-7. 